\title{
TECHNOLOGICAL TRENDS IN THE MANUFACTURING AND SERVICE SECTORS. THE CASE OF MONTENEGRO
}

Nina Vujanović

\section{Abstract}

Technological efficiency is one of the main factors of economic growth in modern history. Technologies have traditionally been important for manufacturing sector, but the age of digitalization has also made service sector increasingly rely on modern technologies. There are not many studies measuring the technological trends of these two sectors. This study uses the micro approach of the dynamic panel to measure productivity of the manufacturing and service sectors in Montenegro during 2010 to 2019, between the two global economic crises, using firm level data. The results indicate a clear upward technological trend in manufacturing but not in the service sector. Divergent technological trends are found amongst the manufacturing and service industries that require different level of technologies and knowledge in their production processes. The study concludes that there is a room for further technological improvements in both sectors and proposes concrete policy measures for further development.

Jel classification: $L 25, M 21,033$

Key words: technological efficiency, manufacturing sector, service sector, economic crisis

\section{INTRODUCTION}

Technological growth is an important motor of growth and a mean to achieve the sustainable development goals too (UNCTAD 2021). Growth of production (output) via increasing technological efficiency (i.e. better use of inputs), is an increasingly important form of fostering economic growth, especially after the COVID 19 pandemic that hit technologically equipped industries less severely. Industires that heavily relied on technologies facilited business continuity despite physical isolation.

However, technological growth can bring about disparities due to job loss, lower wages and profits, but also inabilities of some societies to adopt change. UNCTAD (2021) report explains that the development levels were approximately homogenous across the globe until the onset of the first industrial revolution when economies started diverging. Each subsequent wave of technological change thereof, led to the widening of the gap between technological frontier and technolgocial periphery countries that struggled to employ new technologies sucessfully. Today, only few countries create the technological frontier, such as Switzerland, United Kingdom, Singapore, the Netherlands and the Republic of Korea.

In the aftermath of the COVID 19 pandemic, we may witness new technological trends and new industrial revolution (Crescenzi et al. 2021). Data already show that trade in high-tech goods outperformed trade in goods in 2020 and that these trends continue in 2021 (Miller et al. 2021). Therefore, monitoring technological trends is important, especially for developing and transition economies that are technologically

Nina Vujanović, PhD

Central Bank of Montenegro

E-mail: nina.vujanovic@cbcg.me

Address: Bulevar Sv. Petra Cetinjskog 6

Podgorica, Montenegro

ORCID: https://orcid.org/0000-0001-5861-6981 
inferior to developed economies. Today, in the age of digitalisation, technological efficiency is the basis of economic growth and development. It can be reliably stated that the service sector in particular has undergone major changes in the structure of servicing, precisely because of the period of digitalisation that has further technologically "enriched" these activities.

The manufacturing and service sectors in Montenegro are interesting for research on technological progress for several reasons. First, the two sectors together account for about $44 \%$ of GDP in Montenegro (Monstat 2020), of which as much as $40 \%$ are service industries. The second reason is that these two sectoral activities promote technological growth. Primary industries are less susceptible to technological changes (McMillan and Rodrik 2011). Finaly, globally, these sectors are of particular interest to foreign direct investors. The data indicate that international mergers and acquisitions in service industries account for about $44 \%$ of total international transactions, while manufacturing industry accounted for rougly $49 \%$ in 2019 (UNCTAD 2020). Greenfield investments in the service and manufacturing sectors account for almost half of the total foreign direct investment. Foreign direct investment can boost technological growth as multinational companies undertake the major part of the worlds' R\&D and produce the most advanced production technology (Dunning and Lundan 2008).

However, since technology is an intangible "asset", there is a challenge in understanding the technological trajectories. Hence, this study contributes to research in several ways. First and farmost, it recommends a new approach to measure technological efficiency of the sectors of economy, using firms' financial statements over the 2010 to 2019 period. Measuring technological efficiency, first at the micro level (for each firm), and then via summation at the sectoral level improves the precision in measurement. Second, this study also provides insight into the technological trend of industries that differ in terms of the level of technological development required in production (manufacturing industries), as well as the level of knowledge required in servicing (service industries). Third, by measuring the total factor productivity between the two economic crises, a trend of technological development in the first years after the financial crisis is obtained, as well as in the years immediately before the even greater economic crisis caused by the COVID 19 pandemic. In the wake of new technological wave, characteristed by frontier technologies such as artificial intelligence, internet of things, Big data, blockchain, 3D printing etc. (for more detailes see UNCTAD 2021, p. 17) accurate measurment of technological trends becomes more important. The study period circumvents the two years when Montengro was hit by the Global financial crisis (2009) and COVID 19 crisis (2020) leading to negative GDP growth of $-5,8 \%$ and $-15,2 \%$, respectively. This indicates the dynamics of technological efficiency in two important economic sectors in the period between the two largest negative economic shocks in modern history.

The study is organized in several sections. Section 2 gives a theoretical framework of the importance of technological efficiency for economic development, with special reference to economies in transition. Section 3 provides an insight into the different calculation methods of this phenomenon. Section 4 explains the data and the application of one of the methods for calculating technological efficiency. Section 5 provides a graphical representation of the results. Section 6 concludes and proposes policy measures that could improve technological development of these sectors.

\section{IMPORTANCE OF TECHNOLOGICAL EFFICIENCY - THEORETICAL FRAMEWORK}

Growth of the output of an economy can be the result of the growth of inputs or growth of technological efficiency, the latter representing total factor productivity (TFP). Total factor productivity, i.e. technological efficiency, is an important stimulus to economic development and, in the long run, to the standard of living (Howwit 2000; Hornbeck and Moretti 2018). It can directly affect employment growth and average income. For instance, Hornbeck and Moretti (2018) in their empirical analysis find that $1 \%$ productivity growth in the United States manufacturing sector led to an income growth of $1.45 \%$ between 1980 and 2000. Income growth is more obvious in the case of less skilled workers than more skilled ones, so this study also points to the contribution of productivity in reducing inequality within the United States. However, across the globe technological growth can cause much discrepnacies and inequalities.

Generally, somewhat poorer countries have less savings to reinvest, which reduces not only simple capital accumulation but also the level of intangible assets that can accelerate the technological catching up of high-income economies (Dowrick and Rogers 2002). Therefore, technological efficiency of developing economies is usually lower than technological efficiency in developed economies. This divergence has been only increasing with time, as the latter group shows lower capacity to adopt frontier technologies. Until the first wave of technological growth (first industrial revolution), the level of development across countries was not too different. However, each new 
wave of technological growth brought a greater divergence between technological leaders and technological laggards. UNCTAD (2021) shows that Eastern European countries are, although above the average level of technological development still much behind the technological frontier countries.

Bloom et al. (2010b) explain that in less developed economies a weaker level of competitiveness as well as a large number of family businesses make it difficult for a large number of poorly run firms to survive in the market. The reasons for this is poor management, as well as weaker sources of finance (especially for small firms). It is known that external sources of finance are more expensive in less developed economies. Hornbeck and Moretti (2018) also argue that economies with flexible labour markets have greater potential for technological growth. Labour mobility is possibly lower in countries that have been a part of socialist systems for a long time.

When it comes to transition economies, the issue of technological development until the 1990s was more structural in nature. In general, transition countries inherited older capital structures (machinery and other equipment) and therefore their technological efficiency was significantly lower than in developed western economies. Nishimuzu and Page (1982) indicate that most industries in the Socialist Federal Republic of Yugoslavia (1965-1978) were "mature socialist industries" where greater technological progress was not expected, whereas fewer industries did not record technological growth due to lack of investment. Only a smaller number of industries (production of metals and electrical machines) recorded high technological development. The research indicates that it is highly likely that the starting technological base of the Balkan countries is at a lower level than that of the developed countries.

The period of globalisation and integration of these countries with the rest of the world, through trade exchange, should have influenced technological advancement (McMillan and Rodrik 2011; Bloom et al. 2016c) in their early phase of transition. It is known that technological efficiency can be improved with better knowledge of foreign markets through imports and exports (Alvarez and Lopez 2008). This is because skills and technologies are "imported" from abroad into the domestic economy through trade. Nevertheless, McMillan and Rodrik (2011) warn that the structure of trade has an impact on technological growth. Countries that export natural resources have less chance of technological growth because primary industries employ less labour force than manufacturing industries and services. This is the case with Montenegro, where $50 \%$ of export products are raw materials. ii

The greater opening of these countries has also attracted foreign direct investors. It is known that technologies can be improved through the transfer of knowledge from international companies to domestic entrepreneurs (knowledge spillovers), if domestic entrepreneurs have sufficiently "developed" human capital to implement new technologies. Research indicates some transition economies (Czech Republic, Russian Federation, Lithuania, Bulgaria) did not take full advantage of this type of technological improvement in the earlier transition period (Konings 2001; Djankov and Hoekman 2000; Javorcik 2004; Sabirianova et al. 2004; Kosova 2010).iii Some economies (Republic of Croatia, Republic of Serbia, Bulgaria, Poland, Ukraine, Slovenia, Estonia, etc.) have made better use of this type of technology transfer, specifically in the manufacturing sector at a later stage of transition (Gorodnicheko et al. 2014; Monastiriotis and Alegria 2011; Vujanović et al. 2021). Recent studies also show that the weaker absorption of foreign knowledge is a result of the fact that some transition economies are now closer to the technological advancement of developed economies and thus have less to learn (Vujanović 2018). Unfortunately, there are no studies that address this issue for Montenegro.

In addition, the period of financial crisis has changed the circumstances for further technological development in many countries. Banks have applied very strict lending policies after the global financial crisis, and that could only slow down technological growth. External funding sources are very important for technological development, especially in transition economies (EBRD 2018). Recent research confirms that external funding sources, such as banking loans, are important in transition economies and that restrictive lending policies may negatively affect technological development (Vujanović et al. 2021). This additionally requires monitoring technological trends in periods of economic crisis in these economies.

Apart from divergent development across the globe, technological efficiency is not equally important in all sectors of economy either. A study by McMillan and Rodrik (2011) indicates that productivity in the manufacturing sector is higher than that in the construction sector and even three times higher than in agriculture. In some economies, such as Vietnam, there is a noticeable "shift" of labour from the agricultural sector to the manufacturing sector (McCaig and Pavcnik 2013). On the other hand, a trend of increasing employment in the service sector has been observed in Europe, at the expense of the manufacturing sector, which is a reason why service industries are the main driver of technological development in Europe 
(Uppenberg and Strauss 2010). Namely, the reallocation of human resources from one sector to another changes the potentials of technological growth, as the human capital itself is an important determinant of technological development (Baltagi et al. 2016; Seyoum et al. 2015). In this regard, the importance of technological development of the manufacturing and service sector in the overall economy is growing.

\section{METHODS OF ESTIMATION}

Technological efficiency (total factor productivity), as explained, indicates the efficiency of inputs' use into the production process. As such, technological efficiency is abstract and challenging to measure. Several measures of technological efficiency have been employed to date. For instance, as an approximation of productivity, companies can use sales revenues (Haskel et al. 2007; Barbosa \& Eiriz 2009) and labour productivity, which is measured by the ratio of sales revenues (or value added) per employee (Ruane \& Uĝur 2005; Zhou et al. 2002). The benefit of these productivity measures is in their simplicity and availability.

However, these measures do not take into account immeasurable aspects of technological efficiency. For instance, labour productivity measures the efficiency of the use of labour force into the production process, but not the capital, and is therefore only a partial measure of productivity. Total factor productivity measures the technological efficiency of using both inputs into production. Total factor productivity (TFP) is measured as a residual from the production function. Although it is a more comprehensive measure of productivity, the estimation itself is complex and without adequate implementation this measure is not necessarily superior, which will be clearer latter in the text.

The approach to estimating firm total factor productivity through the production function is explained in Subsection 3.1.

\subsection{Measurment of firm technological efficiency}

Total factor productivity is approximated as the residual of the Cobb Douglas production function, which defines output as a function of production input. The Cobb Douglas production function has the following form:

$$
Y=(T F P) K^{\beta_{1}} L^{\beta_{2}}
$$

$Y$ refers to output of production that is usually approximated by sales proceeds or value added. TFP is the total factor productivity, while $K$ and $L$ represent inputs in the production process - capital and number of employees, respectively. Therefore, total factor productivity is a technological efficiency that contributes to the growth of output, to the extent that it is not contributed by the factors of capital and labour used in production.

$\beta_{1}$ and $\beta_{2}$ represent the coefficients of capitallabour elasticity. Cobb Douglas production function is homogeneous. In other words, if the production factors $K$ and $L$ increase $n$ times, the output $Y$ will increase $t^{n}$ times which makes the production function (1) a homogeneous function of the level $t$.

By logarithming the production function (1), we obtain:

$$
\begin{aligned}
& y_{i t}=\alpha+\beta_{1} k_{i t}+\beta_{2} l_{i t}+w_{i t}+\varepsilon_{i t} \\
& \ln \left(T F P_{i t}\right) \alpha+w_{i t}+\varepsilon_{i t} \\
& \eta_{i t}=w_{i t}+\varepsilon_{i t} \\
& i \text { - firm, } t \text { - year. }
\end{aligned}
$$

$y_{i t}, k_{i t}$ and $l_{i t}$ in equation (2) represent the logarithmic values of output, capital and labour from equation (1). $\alpha$ is a constant denoting the average firm productivity in the initial (base) period. The composite error term $\eta_{i t}$ consists of two components $w_{i t}$ and $\varepsilon_{i t} . w_{i t}$ represents an anticipated productivity shock that is known and predictable to a firm, but not externally. For instance, a firm can anticipate productivity "shocks" resulting from management or some other factors known internally. $\varepsilon_{i t}$ is unanticipated idiosyncratic productivity shocks, caused by some unpredictable factors, such as weather conditions, machine failure, termination of employment contracts and other circumstances. This component of the standard error is independently and identically distributed and as such is not correlated with other variables in regression (2).

The total factor productivity, as a residual component, is obtained as the simple difference between the actual output value $y_{i t}$ and the output value $\hat{y}$ estimated with regression (2). However, the problem in such an estimation of total factor productivity is the various endogeneities inherent to the equation (2). Namely, the management of a firm makes decisions about the number of employees $l_{i t}$ based on its predictable productivity $w_{i t}$. This causes a correlation between the variable $l_{i t}$ and the total composite standard error $\eta_{i t}$ (which contains $w_{i t}$ ). If, as a result of higher productivity, firms increase the number of employees, the coefficient of labour elasticity $\beta_{2}$ is upward bias. All this 
raise the issue of the technological efficiency estimation based on regression (2).

The issue of estimation of the Cobb Douglas production function has given rise to several methodological approaches that aim to annul the mentioned endogeneity, such as Olley \& Pakes (1996), Levinsohn \& Petrin (2003), Ackerberg et al. (2006) and Wooldridge (2009), the first three being explained in the Appendix. The Wooldridge (2009) method is the last in a series that attempts to address the endogeneities caused by the correlation of labour input $l_{\text {it }}$ and productivity $w_{i t}$. Wooldridge (2009) relies the method on Levinsohn \& Petrin (2003) that use material input $m_{i t}$ to approximate unobserved productivity $w_{i t}$, which can under monotonicity assumption (see Appendix) be expressed as $g\left(k_{i t}, m_{i t}\right)$.

Wooldridge proposes a dynamic panel model based on the generalised method of moments, that offers a wide range of instruments for endogenous variables, whose validity can be tested.

Wooldridge (2009) bases the reliability of its method on several key assumptions. The first is that the part of the productivity shock that is unpredictable $\left(\varepsilon_{i t}\right)$ does not depend on current and past decisions on the engagement of labour, capital and raw materials (denoted with $m_{i t}$ ) in the production process. iv Wooldridge also limits the dynamics of the productivity shock $w_{i t}{ }^{v}$ The given assumptions lead to two regressions that are jointly estimated by the dynamic method of generalised moments.

$y_{i t}=\alpha+\beta_{1} k_{i t}+\beta_{2} l_{i t}+g\left(k_{i t}, m_{i t}\right)+\varepsilon_{i t}+\xi_{i t}$

$y_{i t}=\alpha+\beta_{1} k_{i t}+\beta_{2} l_{i t}+f\left(g\left(k_{i t-1}, m_{i t-1}\right)\right)+\varepsilon_{i t}+\xi_{i t}$

Where $\xi_{i t}$ represents innovation and $m_{i t}$ is material input that can approximate productivity. The first equation is based on equation (2) and the fact that productivity can be expressed as a function of capital $k_{i t}$ and raw materials $m_{i t}$, whose values are available in financial statements. The second equation follows from the assumption that productivity $w_{i t}$ follows an autoregressive process of the first order AR (1) according to which productivity $w_{i t}$ is expressed as a function of productivity from the previous period $w_{i t-1}$ and innovation $\xi_{i t}\left(w_{i t}=w_{i t-1}+\xi_{i t}\right)$. With the assumption of monotonic relation between productivity $w_{i t}$ and material input $m_{i t}$, the following formulation of productivity $w_{i t}=f\left[g\left(m_{i t-1}, k_{i t-1}\right)\right]+\xi_{i t}$ explains equation (4).

Equations (3) and (4) are estimated with the GMM method, which takes into account their interdependence (correlation). According to the estimation of this equation, firm TFP is obtained as the difference between the actual value of the output $y_{i t}$ and the estimated output $\hat{y}$.

\subsection{Measurement of sectoral technological efficiency}

Equations (3) and (4) are estimated on the sample of firms within NACE 2 industries. The calculated measures of firm technological efficiency were then summed up at the level of manufacturing and service sector in two steps. First, the weighted average of technological efficiency of NACE 2 industries is calculated on the basis of the technological efficiency of individual firms, followed by the calculation of the weighted average for the subsectors and sectors of economic activities.

When calculating the total factor productivity for each industry and sector of activity, the size of individual firms within the industry was taken into account, but also the size of individual industries (NACE 2 classification) within the sectors themselves. This means that larger firms (with greater number of employees) received a higher weight when "summed up". Similarly, larger industries within the two sectors are higher weighted compared to smaller industries.

The weight represents the ratio of the number of firm employees and the total number of employees in the industrial NACE 2 activity $j$. The given weighting was applied to each industrial activity $j$ within manufacturing/service sector $r$ with the following formula:

$$
T F P_{j r t}=\sum_{i=1}^{N} \text { weight }_{i j r t} * T F P_{i j r t}
$$

$T F P_{i j r t}$ represents total factor productivity (technological efficiency) of a firm $i$ within NACE 2 industry $j$, activity sector $r$ in year $t$. $N$ represents the total number of firms in industry $j$. weight $t_{i j t}$ represents the ratio of the number of employees of a firm $i$ and the total employment of industry $j$, activity sector $r$ in year $t$. This weight gives greater importance to larger firms compared to smaller ones.

Finally, total factor productivity (technological efficiency) of the manufacturing and service sector $r$ was calculated based on the following formula:

$$
T F P_{r t}=\sum_{j=1}^{M} w_{e i g h t}{ }_{j r t} * T F P_{j r t}
$$

Where $M$ represents the number of NACE 2 industries $j$ within the manufacturing/service $r$ in year $t$. weight ${ }_{j r t}$ represents the ratio of the number of employees in industry $j$ and the number of employees in the manufacturing/service sector $r$. This weight therefore gives more "weight" to the technological efficiency of those industrial activities with greater number of employees in the sectoral structure. 


\section{DATA}

Data used for the purposes of estimating total factor productivity are firms' financial statements for the period 2010-2019 available at the Central Bank of Montenegro.vi This database also contains non-financial information on the number of employees, industrial activity of economic entities, as well as the location of businesses. The length of the series is limited by the availability of data on the number of employees, which is available from 2010 onwards. Data on the production price index from the Statistical Office of Montenegro (Monstat) were used alongside the aforesaid data.

The number of employees approximates the labour force $l_{i t}$, equity stands for capital levels $k_{i t}$, while the accounting item "cost of material" was used to approximate the cost of raw materials $m_{i t}$. Firm's value added approximates the output $y_{i t}$ of the Cobb Douglas production function and it is calculated as a simple difference between operating income and raw material costs $m_{i t}$. The value of capital, raw material costs, and operating income (and, therefore, the added value) are deflated using the producer price index. Because of the logarithmic transformation applied, firms with negative values of one or more of the variables indicated above are not included in the estimation because the values of their variables are annulled by logarithm.

The dataset counts 920 to 1,910 of manufacturing firms and 6,714 to 13,767 service firms depending on the year. However, after cleaning missing values of the abovementioned variables, the number of firms significantly reduces for both sectors. The final sample amount to 5,930 observations for manufacturing (602 to 963 firms, depending on a year) and 36,413 observations for services (3,628 to 6,215 firms, depending on a year).vii

Descriptive statistics of variables used for TFP estimation (in logarithmic form) are presented in table 1 (manufacturing) and table 2 (services).

The Wooldrige (2009) method was applied to NACE 2 activity level industries in order to comply with the rule of homogeneity of production function. This means that the method was applied specifically to groups of firms belonging to the same NACE 2 industries within manufacturing and service sector.

Table 3 shows NACE 2 industries within the manufacturing and service sector classified by the level of technology used (manufacturing sector) and the level of sophistication of knowledge required for rendering services (service sector). Eurostat recognizes four subgroups of industries within the manufacturing sector: high-technology (high tech), medium high-technology (med-high), medium low-technology (med-low), and low-technology (low tech). Eurostat distinguishes industries within the service sector to those industries that require a high level of knowledge and expertise in servicing (knowledge-intensive services) and other services.

Total factor productivity of subsectors that differ in technological advancement of manufacturing industries (manufacturing sector) and the level of knowledge and expertise required in servicing services (service sector), as categorized based on Eurostat distribution of industries (Table 3 ) has been calculated in a similar fashion as the sectoral TFP. The results of aggregation at the level of sectors and subsectors obtained by applying formula (6) are presented in Section 5.

Table 1. Descriptive statistics, manufacturing

\begin{tabular}{|l|l|l|l|l|l|}
\hline Variable & Observations & Mean & Std. Dev & Min & Max \\
\hline $\operatorname{Ln}\left(y_{i t}\right)$ & 5,930 & 11.06 & 1.93 & -0.08 & 17.83 \\
$\operatorname{Ln}\left(k_{i t}\right)$ & 5,930 & 10.65 & 2.31 & -0.08 & 17.39 \\
$\operatorname{Ln}\left(m_{i t}\right)$ & 5,930 & 9.99 & 2.14 & 1.52 & 17.94 \\
$\operatorname{Ln}\left(l_{i t}\right)$ & 5,930 & 1.36 & 1.19 & -0.95 & 6.59 \\
\hline
\end{tabular}

Table 2. Descriptive statistics, services

\begin{tabular}{|l|l|l|l|l|l|}
\hline Variable & Observations & Mean & Std. Dev & Min & Max \\
\hline $\operatorname{Ln}\left(y_{i t}\right)$ & 36,413 & 11.24 & 1.92 & -0.08 & 19.05 \\
$\operatorname{Ln}\left(k_{i t}\right)$ & 36,413 & 10.24 & 2.43 & -0.08 & 19.43 \\
$\operatorname{Ln}\left(m_{i t}\right)$ & 36,413 & 8.64 & 2.15 & -0.08 & 16.88 \\
$\operatorname{Ln}\left(l_{i t}\right)$ & 36,413 & 1.14 & 1.12 & -0.95 & 7.61 \\
\hline
\end{tabular}


Table 3. Classification of industries in the manufacturing and service sectors

\begin{tabular}{|c|c|}
\hline Manufacturing sector & ervice sector \\
\hline 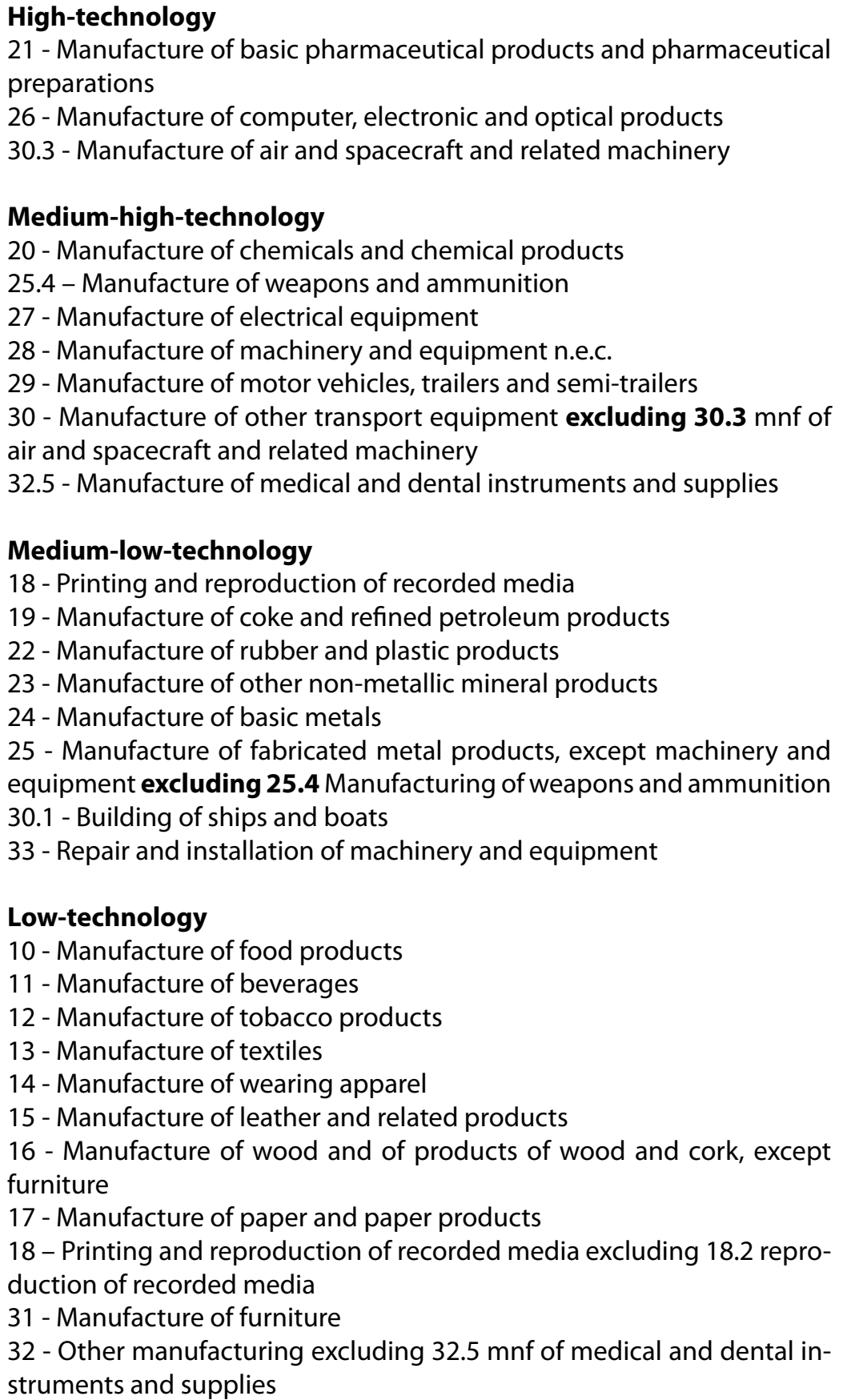 & $\begin{array}{l}\text { High-tech knowledge-intensive services } \\
50 \text { - Water transport } \\
51 \text { - Air transport } \\
58 \text { - Publishing activities } \\
59 \text { - Motion picture, video and television } \\
\text { programme production, sound recording } \\
\text { and music publishing activities } \\
60 \text { - Programming and broadcasting } \\
\text { activities } \\
61 \text { - Telecommunications } \\
62 \text { - Computer programming, consultancy } \\
\text { and related activities } \\
63 \text { - Information service activities } \\
64 \text { - Financial service activities, except in- } \\
\text { surance and pension funding } \\
66 \text { - Activities auxiliary to financial services } \\
\text { and insurance activities } \\
69 \text { - Legal and accounting activities } \\
70 \text { - Activities of head offices; management } \\
\text { consultancy activities } \\
71 \text { - Architectural and engineering activi- } \\
\text { ties; technical testing and analysis } \\
72 \text { - Scientific research and development } \\
73 \text { - Advertising and market research } \\
\text { Other services } \\
45 \text { - Wholesale and retail trade; repair of } \\
\text { motor vehicles and motorcycles } \\
46 \text { - Wholesale trade, except of motor vehi- } \\
\text { cles and motorcycles } \\
47 \text { - Retail trade, except of motor vehicles } \\
\text { and motorcycles } \\
49 \text { - Land transport and transport via } \\
\text { pipelines } \\
52 \text { - Warehousing and support activities for } \\
\text { transportation } \\
53 \text { - Postal and courier activities } \\
55 \text { - Fccommodation } \\
68 \text { - Real andivities }\end{array}$ \\
\hline
\end{tabular}

Source: Eurostatviii and Vujanovic (2018)

\section{RESULTS}

Figure 1 shows the average weighted total factor productivity (technological efficiency) in the manufacturing sector (black line), but also in the subsectors of manufacturing industries that differ in the degree of technological equipping: high-tech, med-high, medlow, and low-tech industries (see Table 1). These are industries whose production processes require high technological equipment (orange line), medium-high technological equipment (grey line), medium-low technological equipment (yellow line), and lowtechnological equipment (blue line). It is clear that the manufacturing sector underwent technological changes in the period between the two economic crises - the financial crisis in 2008/2009 and the COVID 19 pandemic in 2020, although at a lower rate. 
Figure 1. Technological efficiency in the manufacturing sector (2010-2019)

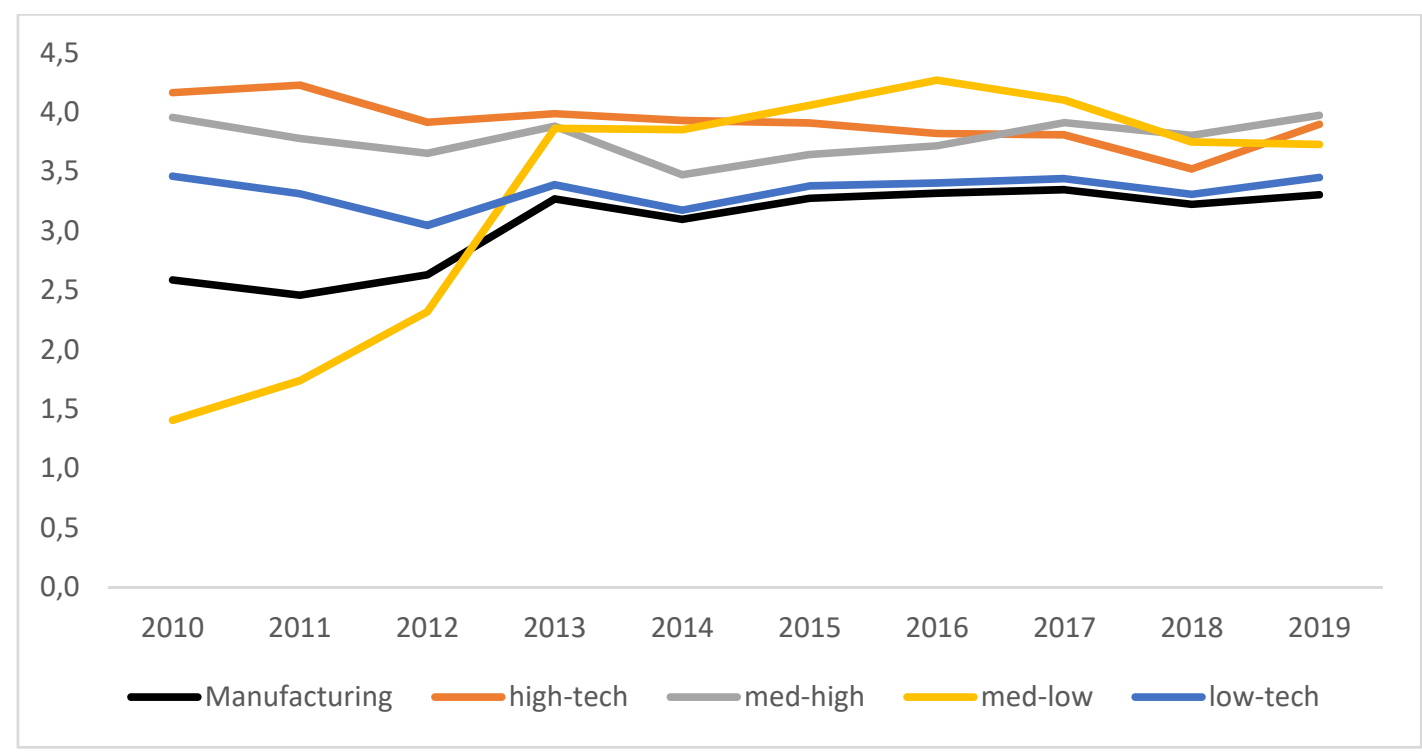

There is an obvious upward trend in the total factor productivity in the manufacturing sector (black line). The upward trend was particularly pronounced in 2013, which can be considered the beginning of the recovery of Montenegro's economy from the financial crisis (see Figure 3A on GDP growth rates, Appendix). This growth trend was somewhat weaker over the period from 2014 until 2019. Namely, there was practically a stagnation in technological efficiency of manufacturing from 2014 until 2018, with the momentum picking up again in 2019. Over the years, technological efficiency of different subsectors has changed. The results indicate that in the immediate aftermath of the financial crisis, technological efficiency of the four sub-sectors were very diverse, yet with similar values in the years preceding the COVID 19 pandemic.

Figure 1 shows that higher-tech industries (orange and grey line) had higher technological efficiency. The most pronounced growth in total factor productivity was of the medium-low tech-industries (yellow line), which before 2013 had visibly lower values than the average sectoral efficiency (black line), only to regain momentum as of 2013. However, in 2019, growth of technological efficiency of the manufacturing sector occurred due to the growth of total factor productivity primarily of high-tech industries, and to a lesser extent due to the growth of medium-high and low-tech industries, while medium-low tech-industries recorded a decline in technological efficiency in 2019.

A similar figure of weighted average sectoral

Figure 2. Technological efficiency in the service sector (2010-2019)

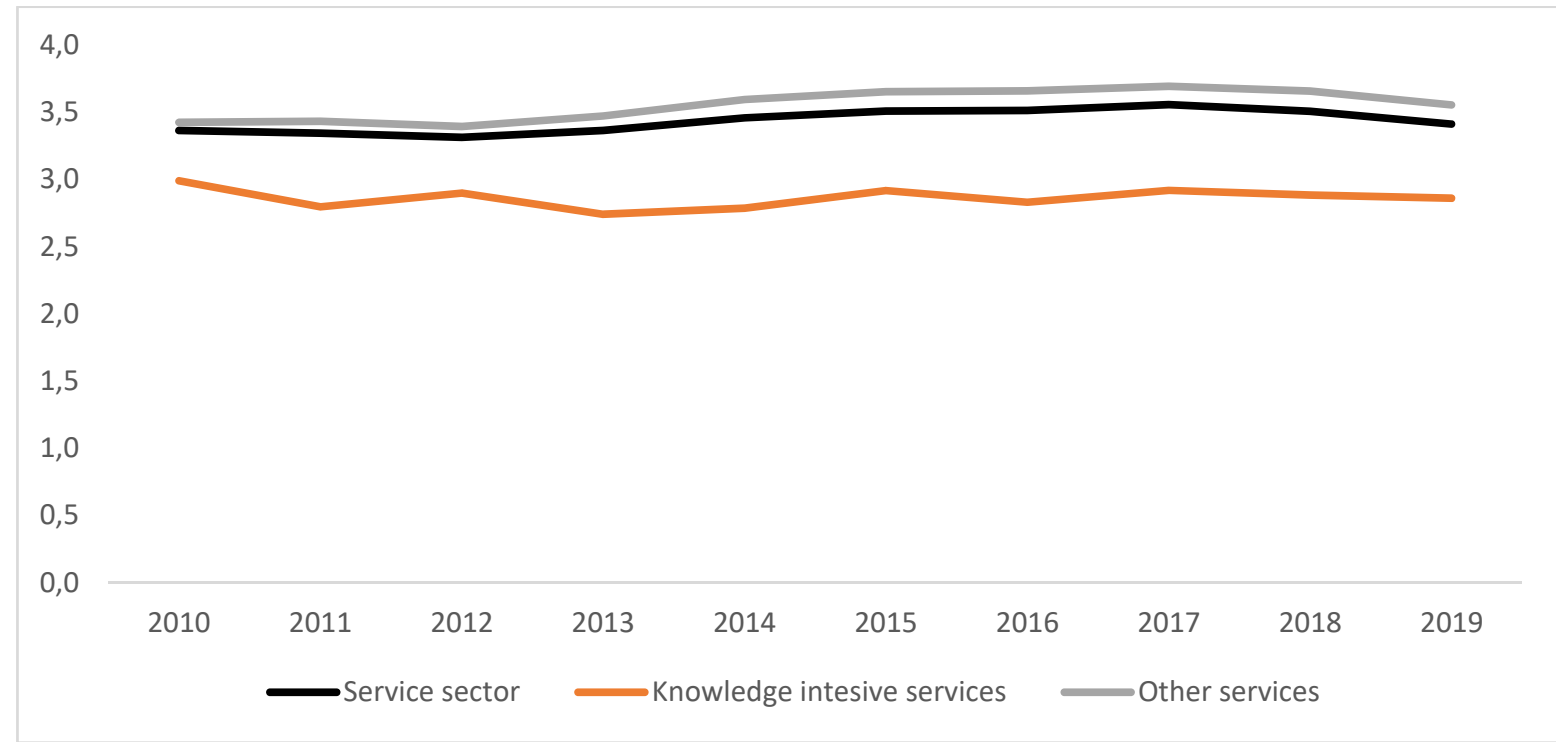


technological efficiency (Figure 2) is given for the service sector (black line), as well as for sub-sectors requiring a high level of knowledge and expertise (orange line) and other services (grey line).

Technological efficiency of the service sector was also on slightly upward trend until 2018, when the level of technological efficiency started to decrease (black line). Figure 2 shows that the trend and value of the average total factor productivity of the service sector were mostly driven by other (less knowledge intensive) services (grey line). Knowledge intensive services have a lower level of technological efficiency, without a pronounced growing trend. These trends in knowledge intensive activities were, according to data, mostly driven by activities in telecommunication industry, legal and accounting activities and management consultancy activities that take up significant share of total employment in knowledge intensive industries (45\% in 2019).

It can be concluded that technological efficiency (total factor productivity) was on an upward trend during the period 2010-2019 in both analysed sectors. However, this trend was more pronounced in the manufacturing sector, possibly due to the different nature of the production process. Manufacturing industries with a strong growth of total factor productivity are medium-low tech sectors, and in the recent past, high to high-medium tech sectors. According to data, this is predominantly due to the rise of production in manufacturing of fabricated metal products and in the industry of repair and installation of machinery and equipment that take up more than $35 \%$ of total employment in med-low tech sector during the 2017 - 2019 period. On the other hand, service industries have maintained a fairly similar level of technological efficiency between the two economic crises, regardless of the period of digitalization that is expected to increase technology growth in the service sector (Wang et al. 2016).

The results of the research are not surprising. UNIDO (2018) report shows that there was a significant increase in manufacturing value added in Montenegro over the 2010 - 2015 period. The manufactured exports per capita increased by $15 \%$ from 2010 to 2015 . Export performance has been traditionally recognised as a channel for technological upgrade (Schoors and Van Der Tol, 2002). Exporters usually have technology that meets international standards and markets, which often is not the case for domestic-oriented firms. This can partially explain the rise of the technological efficiency in the manufacturing industry over this period (see Figure 1). Indicators of export performance and technological deepening were stagnant in later periods (2015-2017), as identified by
UNIDO (2020). Figure 1 shows a clear stagnation in technological efficiency between 2015 and 2019.

On the European Commission's innovation scoreboard, Montenegro is classified in the group of modest innovators, which ranks it among the weakest innovation markets in Europe (European Comission 2020). Although not directly related to technological growth, innovation is an important factor in advancing technologies (Vujanovic, 2018). Therefore, there is a lot of room for economic policy makers to improve technological efficiency. On the other hand, the period after the financial and economic crisis has been marked by restrictive credit policies. As noted, loans are an important source of funding for technology advancement in transition countries. It is possible that this factor also influences the weaker upward trends in technological development of the two sectors.

\section{CONCLUSION AND POLICY IMPLICATIONS}

The twenty-first century indicates that economic growth has been increasingly relying on the growth of technologies and/or better efficiency in the use of production inputs. The crisis caused by the COVID-19 pandemic just further confirmed the importance of technologies that facilitate the manufacturing of products and the rendering of services in the event of negative macroeconomic shocks affecting both supply and demand side. In this sense, industries that have a greater degree of accessibility to technologies in production have a better chance of functioning smoothly in the event of a similar economic crisis.

This study, therefore, provides insight into the technological trends in the two most important economic sectors in Montenegro, manufacturing sector and the service sector in the period 2010-2019, between the two global economic crises. First, the dynamic panel model is applied to the data from the financial statements to obtain technological efficiency of individual firm. Then, the weighted average technological efficiency in the industry and the weighted average technological efficiency of the sector of economy are calculated.

The results of the study indicate that the manufacturing sector recorded a slight uptrend in technological efficiency in the period between the two global economic crises. During the observed ten-year period, the highest growth was recorded by med-low sectors. However, last year we also saw technological growth in high-tech manufacturing sector.

On the other hand, the study indicates that there is much room for technology advancement, particularly in service industries. The service sector has not 
recorded any noteworthy upward trend in technological efficiency, and maybe it is safe to say that it was practically stagnant over the past ten years. The industries that make up the service sector are primarily those that do not require much knowledge and expertise in service rendering. Therefore, it is necessary to change the structure of the service sector, primarily in favour of industries that require greater knowledge and expertise in service provision. Industries that require more knowledge in service provision such as IT, telecommunications, scientific research and development, financial and other service industries have a lot of room for further technological advancement.

It could be concluded that digitalization of Montenegro's economy has not yet gained momentum and economic policies have a wide spectrum of encouraging resources, primarily human capital and knowledge resources, all with the aim of improving technology. Knowledge and human capital are key to the advancement of technologies, but also to their application. In this regard, it is necessary to continuously invest in higher education, but also in attracting domestic and foreign professionals in industries with prospects of further technological growth, namely high-tech manufacturing industries and knowledgeintensive service industries. This would prevent further brain drain.

Montenegro was also assessed as moderate innovator by the European Commission (European Innovation Scoreboard 2020). Innovation is an important factor in technological advancement. Therefore, incentives for research and development, innovation (especially innovation in new production processes) in the form of subsidies and tax reliefs should be increased, as well as further investment in education and training of employees in the field of high technologies. It is necessary to attract foreign direct investments in high-tech manufacturing sectors as well as in service industries that require high knowledge and expertise, and also to encourage their export potential. This will indirectly increase the knowledge and technological advancement of these industries through the adoption of modern technological practices of multinational companies and foreign markets practices. Also, it is necessary to network local suppliers with foreign companies since research indicate that their cooperation improves technologies of companies in domestic supply chains.

The Ministry of Science of Montenegro has made several important steps in the past few years by proposing two reform laws in the field of innovation and technological development that were adopted in 2020. These laws provide a wide range of tax benefits for IT startups and a significant reduction in contributions (of 50\%) for the employment of workers in innovative activities. This is also expected to attract foreign direct investments. Adequate application of the given laws should have a significant impact on further technological advancement.

The construction of the first Science and Technology Park (STP) is under way and its task will be to network the scientific research potential with technology-oriented firms with high growth potential. Establishment of innovation labs, accelerators and incubators in the future may further improve innovation systems because, just like STP, they facilitate cooperation between engeneers, enteprenours ans scientists (UNCTAD 2021). The transfer of knowledge from the academy to the economy should be in focus as it can further enhance technological development in the coming period. The Government incentives through the regulation of the legal framework and the establishment of the aforesaid park provide a framework for further improvement of production technology in selected industries in the coming period, which should be the topic of future research.

Nevertheless, improving technological efficiency is a long-term investment that requires significant fixed costs. This implies that greater financial resources are needed to increase technological efficiency, and in transition economies these are often provided from external sources. Increasing lending to the economy can also encourage the improvement of technological efficiency, especially in high-tech industries.

Athough analysing technological trends over the ten-year period, this study lacks the evidence on technological growth in the time when the economy was hit by the negative macroeconomic shocks caused by the global financial crisis and COVID 19. Even though, Montenegro experienced negative GDP growth in 2012 , there is no strong evidence in this study indicating that the pattern of technological trend was much affected. Future studies should, in their period of study, include the years of negative macroeconomic shocks, and fill in this gap. 


\section{Endnotes}

i From this point onward, (total factor) productivity and technological efficiency are used interchangeably as they represent the same phenomenon (concept). The changing levels of technological efficiency/total factor productivity are referred as technological trends

ii Source: Central Bank of Montenegro internal data for January-June 2020

iii Research generally indicate that economies whose domestic entrepreneurs are suppliers to foreign firms benefited from the knowledge of foreign firms in the early transition period, but not if foreign firms were competitive (in this case, many entrepreneurs lost part of their markets, which has negatively affected investments in technologies).

iv Mathematically:

$E\left(\varepsilon_{i t} \mid l_{i t}, l_{i t}, m_{i t}, l_{i t-1}, k_{i t-1}, m_{i t-1}, \ldots, l_{i 1}, k_{i 1}, m_{i 1}\right)=0$

v $E\left(\mathrm{w}_{\mathrm{it}} \mid \mathrm{w}_{\mathrm{it}-1}, \ldots \mathrm{w}_{\mathrm{i} 1}\right)=E\left(\mathrm{w}_{\mathrm{it}} \mid \mathrm{w}_{\mathrm{it}-1}\right) ; t=2,3, \ldots T$

vi Every year the Tax Administration forwards financial statements of business entities to the Central Bank of Montenegro.

vii See Table 1a and 2a in the Appendix, for more information on the loss of observation through data cleaning.

viii Source: https://ec.europa.eu/eurostat/ statistics-explained/index.php/Glossary:Hightech_classification_of_manufacturing_industries and https://ec.europa.eu/ eurostat/statistics-explained/index.php/ Glossary:Knowledge-intensive_services_(KIS)

\section{REFERENCES}

Ackerberg, D., Caves, K., \& Frazer, G. 2006. Structural identification of production functions. http://econpapers.repec.org/paper/ pramprapa/38349.htm (accessed on September, 9, 2020)

Alvarez, R., \& López, R. A. 2008. Is exporting a source of productivity spillovers?. Review of world economics, 144(4), 723-749.

Baltagi, B. H., Egger, P. H., \& Kesina, M. 2016. Firm-level productivity spillovers in China's chemical industry: A spatial Hausman-Taylor approach. Journal of Applied Econometrics, 31(1), 214-248.

Barbosa, N., \& Eiriz, V. 2009. Linking corporate productivity to foreign direct investment: An empirical assessment. International Business Review, 18(1), 1-13.

Bloom, N., Mahajan, A., McKenzie, D., \& Roberts, J. 2010a. Why do firms in developing countries have low productivity?. American Economic Review, 100(2), 619-23.

Bloom, N., Sadun, R., \& Van Reenen, J. 2010b. Recent advances in the empirics of organizational economics. Annu. Rev. Econ., 2(1), 105-137.

Bloom, N., Draca, M., \& Van Reenen, J. 2016c. Trade induced technical change? The impact of Chinese imports on innovation, IT and productivity. The review of economic studies, 83(1), 87-117.

Crescenzi, R., lammarino, S., loramashvili, C., Rdoriguez-Pose, A., Stroper, M. 2021. The shifting global geography of innovation. https://oecd-development-matters.org/2021/03/25/ the-shifting-global-geography-of-innovation/amp/?_twitter_ impression=true (accessed on April 10, 2021)

Djankov Simeon, \& Hoekman Bernard. 2000. Foreign investment and productivity growth in Czech enterprises. The World Bank Economic Review, 14(1), 49-64.

Dowrick, S., \& Rogers, M. 2002. Classical and technological convergence: Beyond the Solow-Swan growth model. Oxford Economic Papers, 54(3), 369-385.

Dunning, J., \& Lundan, S. 2008. Multinational enterprises and the global economy (2nd ed. / John H. Dunning, Sarianna M. Lundan ed.). Cheltenham: Edward Elgar Ltd. http://lib.myilibrary. com?ID=177936 (accessed on July 1, 2020)

EBRD. 2018. Sustaining growth. The Transition Report 2017-18. London: European Bank for Reconstruction and Development.

European Commission. 2020. 2020 European innovation scoreboard. https://ec.europa.eu/commission/presscorner/detail/en/ qanda_20_1150 (accessed on January 30, 2021)

Gal Peter, N. 2013. Measuring total factor productivity at the firm level using OECD-ORBIS. OECD Economic Department Working Papers (1049). https://search.proquest.com/ docview/1371420975 (accessed on October 15, 2020)

Gorodnichenko, Y., Svejnar, J., \& Terrell, K. 2014. When does FDI have positive spillovers? Evidence from 17 transition market economies. Journal of Comparative Economics, 42(4), 954-969.

Haskel Jonathan, E., Pereira Sonia, C., \& Slaughter Matthew, J. 2007. Does inward foreign direct investment boost the productivity of domestic firms? The Review of Economics and Statistics, 89(3), 482-496.

Hicks, J. R. 1963. The theory of wages. Springer. 
Hornbeck, R., \& Moretti, E. 2018. Who benefits from productivity growth? Direct and indirect effects of local TFP growth on wages, rents, and inequality (No. w24661). National Bureau of Economic Research.

Howitt, P. 2000. Endogenous growth and cross-country income differences. American Economic Review, 90(4), 829-846.

Javorcik Beata Smarzynska. 2004. Does foreign direct investment increase the productivity of domestic firms? In search of spillovers through backward linkages. The American Economic Review, 94(3), 605-627.

Konings, J. 2001. The effects of foreign direct investment on domestic firms: Evidence from firm-level panel data in emerging economies. Economics of Transition, 9(3), 619-633.

Kosová, R. 2010. Do foreign firms crowd out domestic firms? The Review of Economics and Statistics, 92(4), 861-881.

Levinsohn James, \& Amil Petrin. 2003. Estimating production functions using inputs to control for unobservables. The Review of Economic Studies, 70(2), 317-341.

McCaig, B., and Pavcnik, N. 2013. Moving out of agriculture: structural change in Vietnam (No. w19616). National Bureau of Economic Research.

McMillan, M. S., \& Rodrik, D. 2011. Globalization, structural change and productivity growth (No. w17143). National Bureau of Economic Research.

Miller, J. and Wunsch-Vincent, S. 2021. High-tech Trade Rebounded Strongly in the Second Half of 2020, with New Asian Exporters Benefiting, World Intellectual Property Organization. https://www.wipo.int/pressroom/en/ news/2021/news_0001.html (accessed on April 1, 2021)

Monstat 2020. Gross Domestic Product in Montenegro in 2019, Montenegro Statistical Office. https://www.monstat.org/eng/page.php?id=163\&pageid=19 (accessed on April 5, 2021)

Monastiriotis, V., \& Alegria, R. 2011. Origin of FDI and intraindustry domestic spillovers: The case of Greek and European FDI in Bulgaria. Review of Development Economics, 15(2), 326-339.

Nishimizu, M., \& Page, J. M. 1982. Total factor productivity growth, technological progress and technical efficiency change: dimensions of productivity change in Yugoslavia, 1965-78. The Economic Journal, 92(368), 920-936.

Olley, G. S., \& Pakes, A. 1996. The dynamics of productivity in the telecommunications equipment industry. Econometrica, 64(6), 1263-97.

Ruane, F., \& Uğur, A. 2005. Foreign direct investment and productivity spillovers in Irish manufacturing industry: Evidence from plant level panel data. International Journal of the Economics of Business, 12(1), 53-66.

Sabirianova Peter, K., Jan Svejnar, \& Katherine Terrell. 2004. Distance to the efficiency frontier and FDI spillovers. IZA Discussion Paper Series, 1332. https://www.econstor.eu/ handle/10419/20601 (accessed on July 15, 2020).
Schoors, K., \& Van Der Tol, B. (2002). Foreign direct investment spillovers within and between sectors: Evidence from Hungarian data. Working Papers of Faculty of Economics and Business Administration, Ghent University, Belgium, 2002/157.

Seyoum, M., Wu, R., \& Yang, L. 2015. Technology spillovers from Chinese outward direct investment: The case of Ethiopia. China Economic Review, 33, 35-49.

UNCTAD (United Nations Conference on Trade and Development). 2020. International Production Beyond the Pandemic, World Investment Report, New York, United Nations. https://unctad.org/en/pages/ PublicationWebflyer.aspx?publicationid=2769 (accessed on June 30, 2020)

UNCTAD (United Nations Conference on Trade and Development). 2021. Technology and Innovation Report 2021: Catching technological waves Innovation with equity, United Nation Conference on Trade and Development, Geneva, Switzerland. https://unctad.org/page/technologyand-innovation-report-2021 (accessed on April 1, 2021)

UNIDO (United Nations Industrial Development Organization). 2018. Demand for manufacturing: Driving inclusive and sustainable industrial development, Industrial Development Report. https://www.unido.org/ resources-publications-flagship-publications-industrialdevelopment-report-series/industrial-development-report-2018 (accessed on April 5, 2021)

UNIDO (United Nations Industrial Development Organization). 2020. Industrializing in the digital age, Industrial Development Report. https://www.unido.org/resourcespublications-flagship-publications-industrial-development-report-series/idr2020 (accessed on April 5, 2021)

Uppenberg, K., \& Strauss, H. 2010. Innovation and productivity growth in the EU service sector. Luxembourg: European Investment Bank.

Van Beveren, I. 2012. Total factor productivity estimation. Journal of Economic Surveys, 26(1), 98-128.

Vujanović, N., Stojčić, N., \& Hashi, I. 2021. FDI spillovers and firm productivity during crisis: Empirical evidence from transition economies. Economic Systems, doi.org/10.1016/j. ecosys.2021.100865

Vujanovic, N. 2018. FDI spillovers in selected SEE economies: sectoral and spatial diversities, Doctoral Dissertation, Staffordshire University.

Wang, Q., Zhao, X., \& Voss, C. 2016. Customer orientation and innovation: A comparative study of manufacturing and service firms. International Journal of Production Economics, 171, 221-230.

Wooldridge, J. M. 2009. On estimating firm-level production functions using proxy variables to control for unobservables. Economics Letters, 104(3), 112-114.

Zhou, D., Li, S., \& Tse, D. K. 2002. The impact of FDI on the productivity of domestic firms: The case of China. International Business Review, 11(4), 465-484. 


\section{A OLLEY \& PAKES (1996), LEVINSOHN \& PETRIN (2003), ACKERBERG ET AL. (2006) METHODS OF PRODUCTIVITY ESTIMATION}

Olley \& Pakes (1996) - OP approximate productivity with the level of investment, assuming that there is a strict positive correlation between investment and productivity and that this relationship is monotonically increasing. Therefore, they express the productivity $w_{i t}$ as a function of investments $i_{i t}$ and capital $k_{i t}\left(w_{i t}=g\left(i_{i t}, k_{i t}\right)\right)$.

Levinsohn \& Petrin (2003) - LP believe that the OP method is not an adequate method as investments are highly volatile and as such cannot approximate productivity $w_{i t}$ which, essentially, has a more predictable trend. Therefore, the assumption of a monotonically increasing relationship between productivity and investment is not justified. LP suggest that the costs for raw materials in production (electricity, fuel, and the like) which values are available in the financial statements are used to approximate productivity $w_{i t}$. Therefore, they express productivity as follows: $w_{i t}=g\left(m_{i t}, k_{i t}\right)$, where $m_{i t}$ represents the cost of raw materials in production. Both methods, OP and LP, have great similarities and rely on the strict monotonicity assumption. These methods estimate the Cobb Douglas function (2) in two steps. In the first step, the coefficient of capital elasticity $\left(\beta_{1}\right)$ is estimated, while in the second step, the coefficient of labour force elasticity $\left(\beta_{2}\right)$ is estimated.

Ackerberg et al. (2006) - ACF consider that OP and LP methods are not reliable because the monotonicity assumption is not realistic in any case. Additionally, the ACF indicate that the assumption about the timing of the decision on labour force is important. Namely, if the decision on labour force is made at the same time when the decision on investments and purchase of raw materials is made, then the problem of endogeneity is neither solved by OP nor LP methods. The ACF propose an additional assumption on the timing of making decision to purchase raw materials, labour force, and the capital.

The Wooldridge (2009) method is the last in a series that attempts to address the endogeneities caused by the correlation of labour input $l_{i t}$ and productivity $w_{i t}$. As indicated, it derives from previous methods, correcting their shortcomings, and in this sense is the most advanced. Wooldridge criticizes that the two steps (characterised by the OP, LP, and ACF methods) in estimation of equation (2) are correlated and that they have the problem of heteroskedasticity and autocorrelation, and are therefore unreliable.

Table 1a. Number of manufacturing firms during 2010-2019 period, before and after cleaning

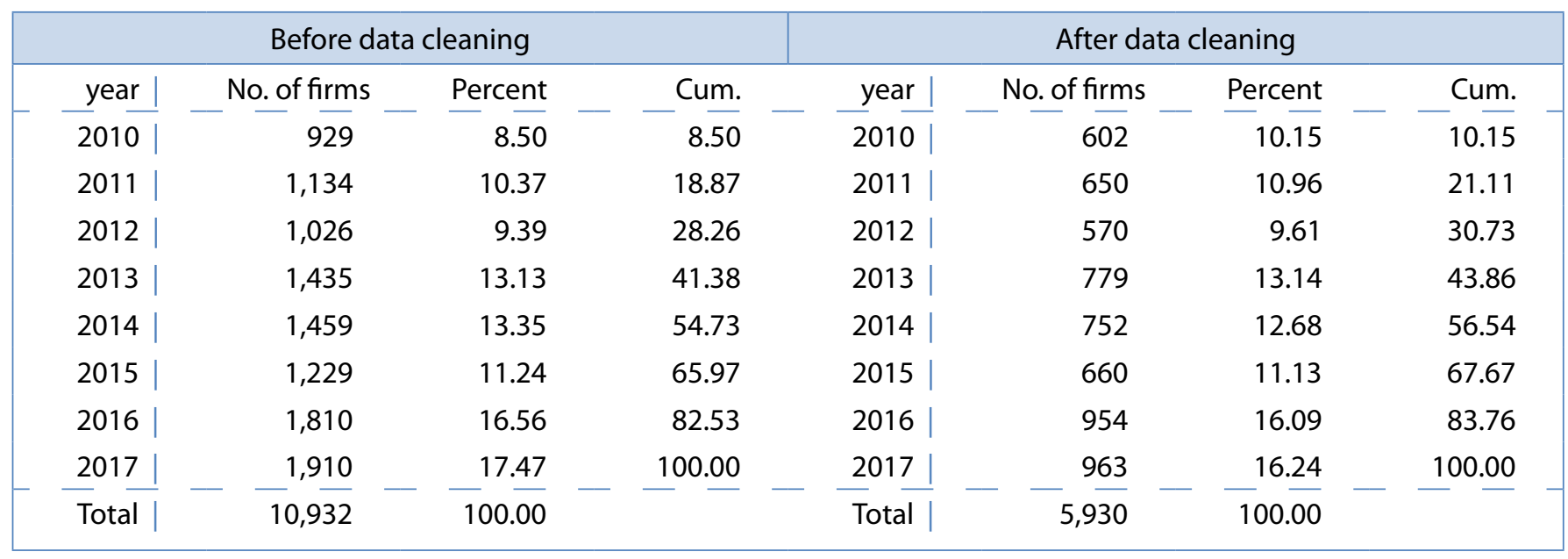


Table 2a. Number of service firms during 2010-2019 period, before and after cleaning

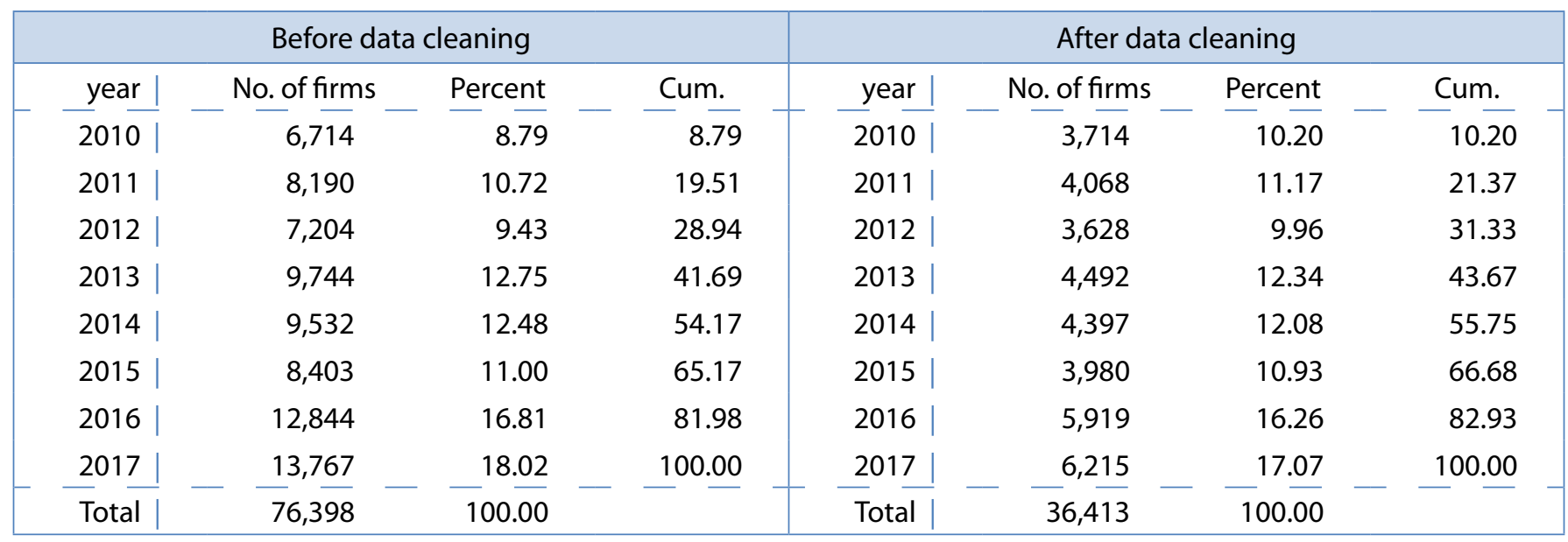

Figure 3a. 2010-2019 GDP growth rate, Montenegro

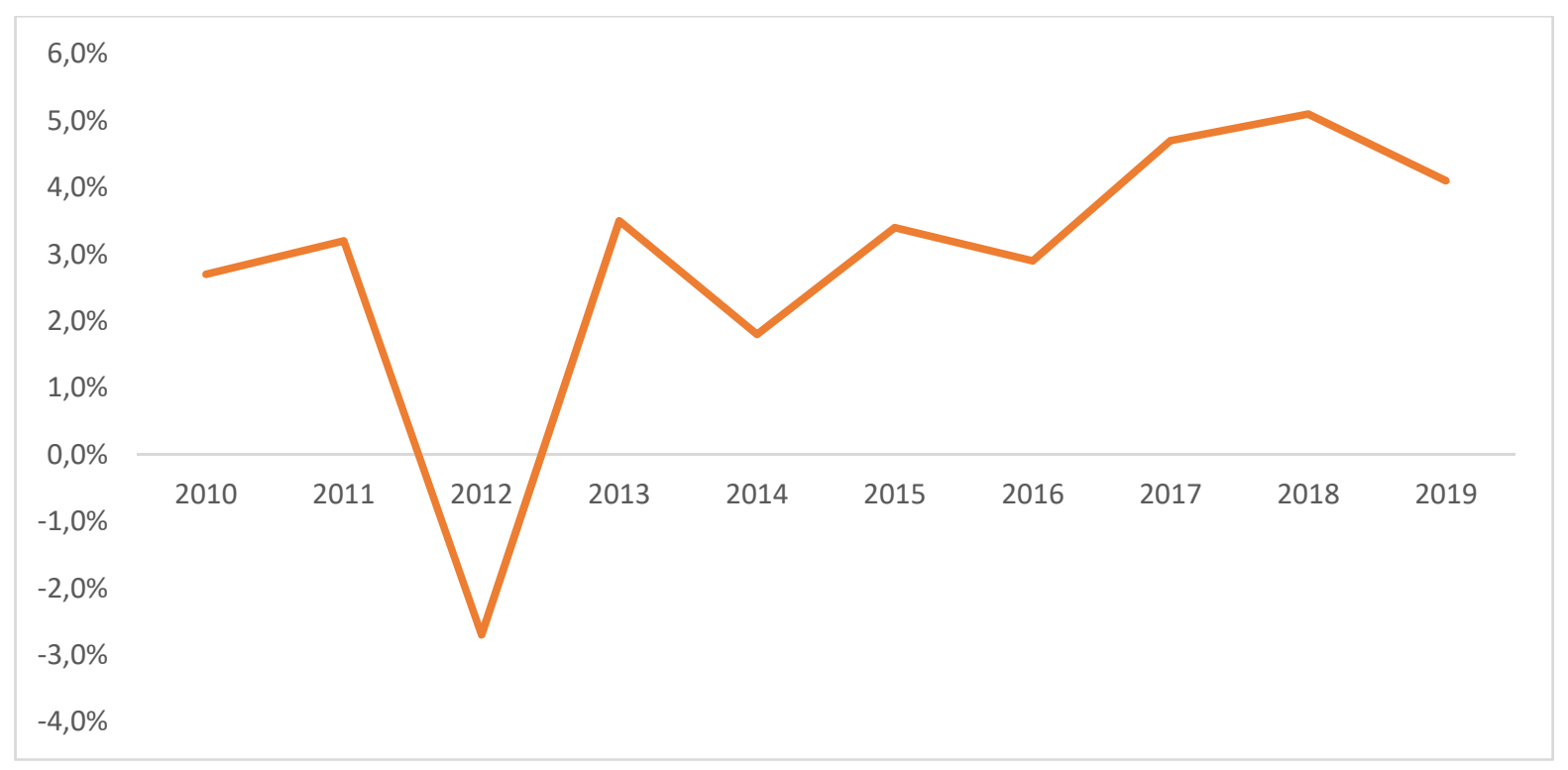

